\title{
A STUDY OF MAINTAINING PRIVATE GARDEN AND DISPARITIES IN CONSCIOUSNESSES ASSOCIATED WITH OPENING OR CLOSING PRIVATE GARDEN 自宅の庭の維持管理と開放・閉鎖する意識の差異に関する検討
}

\author{
Jun SANBUICHI* and Akira YUZAWA** \\ 三分一 淳，湯 沢 昭
}

\begin{abstract}
The aim of this study is to clarify the consciousness structure of the garden of home is maintaining managed and the difference of the consciousness of opened person and closed person. The focus of research is quantifying consciousness, merit(the enchantment of Open Garden), and demerit(fear and resistant of Open Garden) by analyzing residents consciousness. An investigation method is a questionnaire to the resident. In analysis of resident's consciousness, factor analysis and covariance structural analysis were performed using the result of resident's consciousness survey. The analysis results showed that the consciousness structure of the garden of home is maintaining managed and the difference of consciousness that opens or closes garden of home.
\end{abstract}

Keywords: consciousness structure, Open Garden, evaluation

意識構造, オープンガーデン, 評価

\section{Introduction}

Japanese used to live their life through economic and cultural activities in the community around a home, whereby the territorial connection was very strong and formed sound residential environments. As the social infrastructure hardware was developed and the software was improved, people dramatically changed their social consciousness as well as their social behaviors or activities. In particular, phenomenally advanced transportations and the Information technology enable people to live their life virtually or physically away from community residents or home. Eventually, people do not often communicate with other people, whereby the territorial connection weakens. Such few communication opportu nities and weaker territorial connection also lower their interest in the community to be maintained and managed as a living territory.

The above facts point out that the social infrastructure should have been developed on both people's internal and external (mental and material) aspects. It suggests the necessity for the future city planning to place more emphases on people's internal aspects, i.e., the social consciousness.

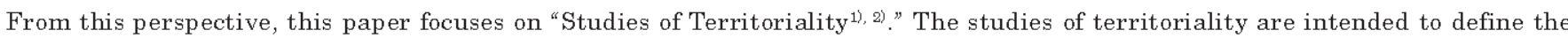
human territory by comparing with animal territories in the animal ecology and the bio-engineering fields. As the study identifies quite a few disparities between animal and human territories, the territory of human beings is distinguished and defined as a "social field," which recently has been advocated. The Study of Territoriality shows that human beings often take certain processes to establish their social field from building territorial consciousness (a sense of ownership) to their properties and space, to increasing openness (consciousness of openness) to the public via forming a territory (see Fig.1).

Consciousness of openness means sharing things and spaces cognized as owned (management) by each person with his or her community or any other people. In other words, his or her consciousness goes toward opening his/her territory to the public. The consciousness of openness is translated into various activities such as participation in volunteer activities, community events, etc., although commitment to such activities differs from person to person. It is pointed out that the activities produce intercommunica tions in the community and improve disaster and crime prevention aspects ${ }^{3)}$ and eventually contribute to improving the residential environments ${ }^{4)}$ or virtuous circle in the community. In light, to orient every resident's consciousness toward the consciousness of openness is appropriate for the future city planning which focus on people's mental side.

* Graduate Student, Graduate School of Maebashi Institute of Technology, M. Eng.

** Prof., Maebashi Institute of Technology, Dr. Eng.
前橋工科大学大学院 大学院生・修士(工学)

前橋工科大学 教授. 工博 


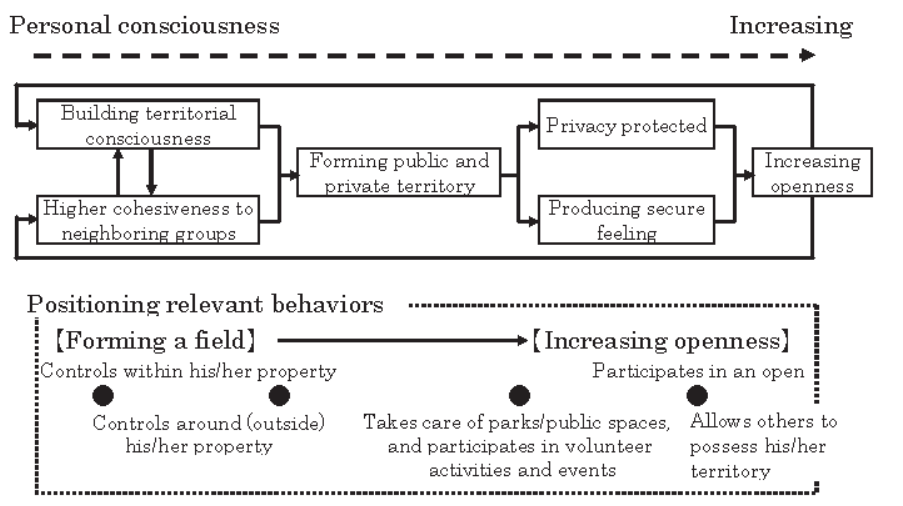

Fig. 1 Processes of improvement of communities/living environments (virtuous circle) and relevant behaviors

There are many papers about creating a social field (circulation) including increasing openness, rising territorial consciousness and forming a territory. The initial studies of rising territorial consciousness and the studies of the stage of forming a territory were intended to illuminate the trend of the circulation through the image mapping and spatial cognition in the former, and people's behaviors and their outpouring behaviors in the latter. Of these papers, the closer one to this study are the studies by Saitou ${ }^{5)}$ and Tsukahara ${ }^{6)}$ regarding to transforming people's con' sciousness in the processes of creating a field, and the studies of the relation between creation of a field and a community by Kamata et al $^{\text {7), }}$, and Saito ${ }^{8), 99}$. Our essay is also close to the studies of concerns about overlapping territories by Inoue et $\mathrm{al}^{10\}}$, Hikino et $\mathrm{al}^{11\rangle}$, Saito et $\mathrm{al}^{12}$, Nakanishi et $\mathrm{al}^{13}$ ), and Hashimoto ${ }^{14)}$, and the study of the consciousness of openness(in houses) by Ichiumi ${ }^{15}$. The studies above are considered as associated with creation of a social field (or its process), whether or not they have definitions or words of territory and social field. The creation of a social field appears to be critical as evidenced by the fact that many researchers focus on it. The activities to create an open garden(hereinafter referred to as the "OG") are also studied by Aida et al ${ }^{16}$, $\mathrm{Nonaka}^{17 \%}{ }^{18)}$. The studies above, however, did not attempt to draw and demonstrate indexes of all processes to the creation of a social field. They did not determine what consciousness community residents should be collectively oriented to for the creation of a social field. As to the opening a personal territory to the public deemed as useful for creating a social field, what make residents unwilling to open their territory to the public or what consciousness makes them willing to do remain unknown. To develop proper policies and determine the direction where the future city planning should go, it is considered important to draw the indexes and identify residents' consciousness and the issues in the process toward opening the territory to the public.

From this perspective, this paper will identify the consciousness leading to maintaining private garden which is a process of forming a territory, and will apply the results for drawing the indexes of the processes to create a field. To orient community residents' consciousness to opening their territory (garden) to the public, this paper will identify disparities in the consciousness between the people who open their territory to the public and those who do not by evaluating the behaviors (activities) of both groups. Thereby, it is possible to constitute fundamental references for the future town and city planning etc.

\section{Methods of Study}

This study follows the flow chart as shown in Fig.2.

\section{(1)Illustrating structure of consciousness}

This section is intended to illustrate the structure of consciousness associated with maintaining a private garden (primary territory ${ }^{19)}$ or core territory $\left.{ }^{20}\right)$ and use the structure as part of the reference materials to draw indexes of all processes to the creation of a social field. This section will select consciousness which seems to be associated with maintaining a private garden. It is stressed by Saito ${ }^{211}$, Oikawa and four other researchers ${ }^{22)}$, Kawane and two other researchers ${ }^{23}$, Fujisaki and three other researchers ${ }^{24)}$ that the consciousness of maintaining his or her garden is strongly linked with so to ${ }^{\circ}$ called green consciousness. Kamei and three other researchers ${ }^{25)}$ and Masuyama and two other researchers ${ }^{26)}$ pointed out the significance of the relationship with neighbors, the attachment to and the secure feeling in the 


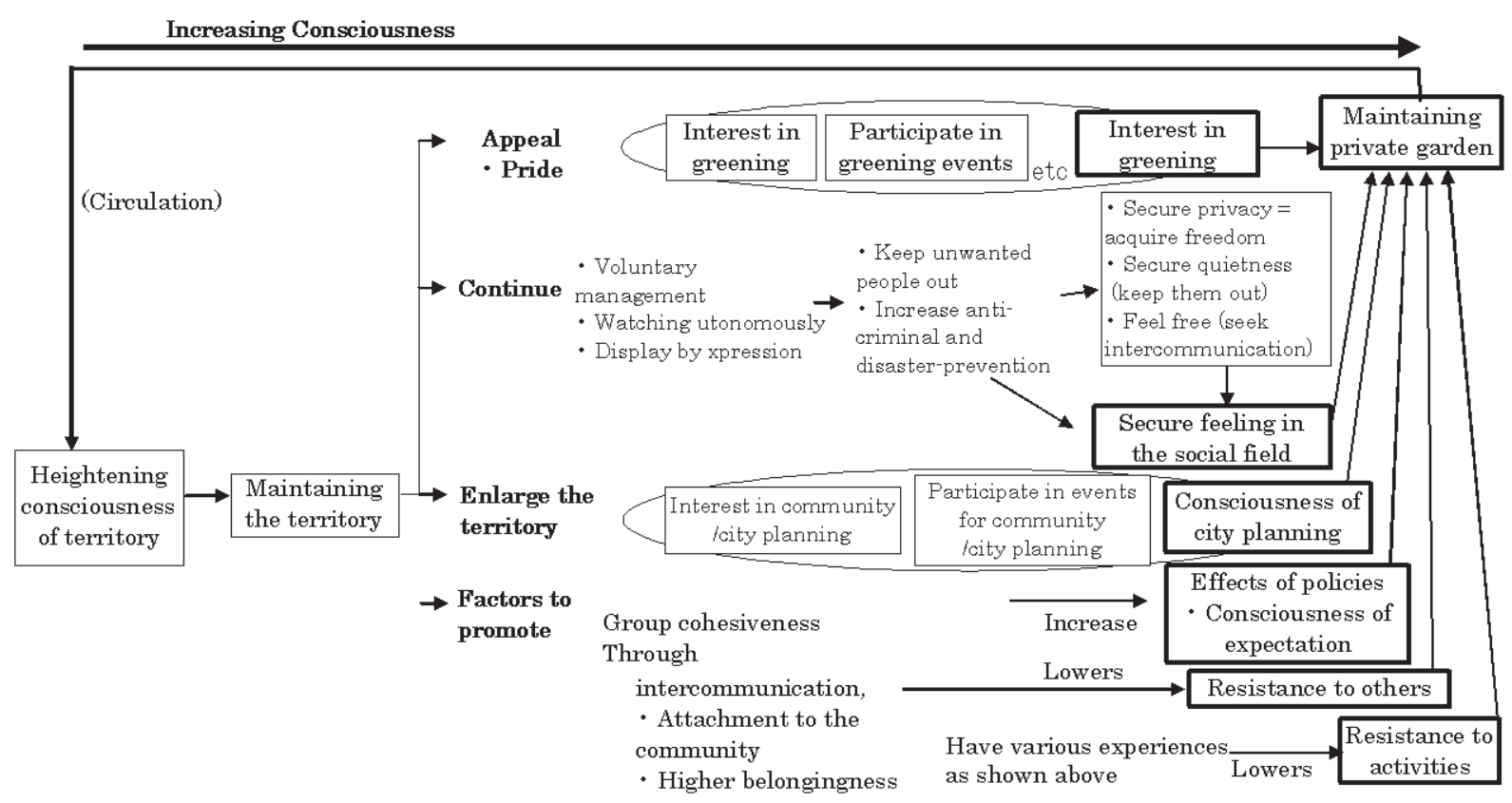

Fig. 3 Consciousness assumed to be related to maintaining private garden (process of transforming consciousness)

community, while Hayashi and other one researcher ${ }^{2 \gamma}$ the significance of the consciousness of building the community. Based on these precedent research results, Sanbuichi and two other researchers ${ }^{28)}$ tried to comprehensively quantify these consciousnesses and demonstrate if there were such consciousnesses or not. Referring to these research results, this paper Based on the preset consciousnesses, questions (evaluation items) are developed and the survey is conducted to people who maintain their garden. Factor and covariance structure analyses will be performed on all obtained data to demonstrate the existence of the preset consciousness and to quantitatively measure the importance of observed variables (path coefficients). They will be weighed in connection with the strength of consciousness of openness later in this paper.

(2)Identifying disparities in OG evaluation between people who open their garden to the public and those who do not

For opening a personal territory to the public, which is useful for the future city planning, this paper considers the OG activities out of various activities as an act of opening a personal territory to the public. For the purpose of the survey, OG activities mean those conducted through opening private properties to the general public by courtesy of the owners of the sample gardens (this evaluation generally uses the garden within the premises of each personal residence; the definition of the garden is not always clear in association with the cooperators or the managers of the sample gardens; and this paper rather chose the words, private property (es)) under the predetermined rules for a certain period of time. Based on the above, these activities should be directed to the maximum openness to the public, contribution to the regional environments and leading sound and virtuous circulation, or approximate the residents' consciousness to the consciousness which motivates them to participate in the activities.

The OG evaluation will be carried out for the people who maintain their garden by the questionnaire similarly to the above. They will be also asked if they particip ate in the OG activities. For the information, appeals, concerns and resistance to the OG were measured in the OG evaluation, which are possible concerns of the sample participants. All obtained responses will go through the factor and covariance structural analyses to determine the structural model of consciousness, based on which the importance of latent variables will be determined by group of people who open or who do not open their garden to the public. This paper will identify the disparities and issues among the people who open their garden to the public and those who do not, and will discuss the direction to the consciousness of openness. For the information, the authors chose the sample area near Shikishima cho, Maebashi, Gunma (named as Midorigaoka Danchi). This area had the OG evaluation before on 18 sample residents for the 2008 National Greening Campaign Gunma (total 17 days of March 29 and 30, April 29 to May 6, and May 19 to 25). Neighboring residents are, therefore, very familiar with OG activities, and it was easy for them to image what the $O G$ evaluation would go. There are public facilities near the area including city parks such as Shikishima Park (a rose garden); therefore, the residents are very green conscious. The authors thought that the OG evaluation was quite feasible in such area. The density of population is about 10.8 per hectare as of the end of September $2007^{29}$. The area is zoned as the primary exclusive low-rise residential district (the area's outskirts are zoned as the primary exclusive middle to high-rise residential area and the secondary exclusive middle to high-rise residential area), and many single houses with garden dot in the town as the best observed.

\section{Survey Results}

For the survey, the questionnaires were posted to the sample area, and collected the responses by mail (distributed on February 14 and 
Table 1 Individual Attributes of Respondents

\begin{tabular}{|c|c|c|c|}
\hline Attributes & $\%$ & Attributes & $\%$ \\
\hline $\begin{array}{l}\text { Gender: } \\
\text { Male }\end{array}$ & 48.4 & $\begin{array}{l}\text { Area of garden } \\
\text { (space for flowers and greens) }\end{array}$ & \\
\hline Female & 48.4 & Below 33 meters square & 30.6 \\
\hline Non'responder & 3.2 & 30 to less than 60 meters square & 26.1 \\
\hline Age: & & 60 to less than 100 meters square & 9.6 \\
\hline $20 \mathrm{~s}$ & 0.6 & 100 to less than 130 meters square & 11.5 \\
\hline $30 \mathrm{~s}$ & 4.5 & 130 to less than 165 meters square & 6.4 \\
\hline $40 \mathrm{~s}$ & 8.9 & 165 to less than 250 meters square & 5.1 \\
\hline $50 \mathrm{~s}$ & 14.0 & 250 to less than 330 meters square & 7.0 \\
\hline $60 \mathrm{~s}$ & 30.6 & 330 to less than 500 meters square & 2.5 \\
\hline $70 \mathrm{~s}$ or greater & 41.4 & esponder & \\
\hline Years of residence: & & \multirow{6}{*}{\multicolumn{2}{|c|}{$\begin{array}{l}\text { Distributed questionnaire sheets: } 800 \\
\text { Effective collected response sheets: } 15 \\
\text { Effective response rate: } 18.8 \%\end{array}$}} \\
\hline 5 vears or shorter & 7.6 & & \\
\hline 5 to less than 10 vears & 8.9 & & \\
\hline 10 to less than 15 vears & 8.9 & & \\
\hline 15 to less than 20 vears & 7.0 & & \\
\hline 20 vears or longer & 67.6 & & \\
\hline
\end{tabular}

Table 3 Results of Factor Analyses of Consciousnesses (after Varimax Rotation)

\begin{tabular}{|c|c|c|c|c|c|c|c|}
\hline $\begin{array}{l}\text { Name of } \\
\text { Variables }\end{array}$ & factor 1 & factor2 & factor3 & factor 4 & factor5 & factor6 & factor 7 \\
\hline " A1 & $0.807 \%$ & 0.032 & 0.143 & 0.088 & 0.164 & 0.055 & 0.070 \\
\hline A2 & $0 / 45$ & 0.046 & 0.172 & 0.072 & 0.154 & 0.155 & 0.060 \\
\hline $\mathrm{A3}$ & 0.642 & 0.154 & 0.060 & 0.242 & 0.116 & 0.061 & 0.120 \\
\hline D1 & 0.065 & 0.915 & 0.101 & 0.126 & 0.094 & 0.091 & 0.106 \\
\hline D2 & 0.080 & 0.793 & 0.037 & 0.168 & 0.030 & 0.120 & .191 \\
\hline D3 & .353 & 0.608 & 0.191 & 0.244 & 0.059 & -0.063 & 0.037 \\
\hline F1 & .080 & 0.000 & 0.989 & 0.072 & 0.111 & 0.024 & .164 \\
\hline F2 & 219 & -0.009 & 0.704 & 0.023 & 0.141 & -0.041 & 0.139 \\
\hline F3 & .119 & 0.228 & 0.572 & 0.084 & 0.127 & 0.062 & -0.177 \\
\hline C1 & 118 & 0.206 & 0.042 & $0 \% 86 \%$ & 0.165 & 0.031 & 0.039 \\
\hline $\mathrm{C} 2$ & .202 & 0.155 & 0.130 & 0.664 & 0.117 & 0.152 & 0.222 \\
\hline C3 & 0.189 & 0.107 & 0.082 & a.sath. & 0.325 & 0.213 & 0.224 \\
\hline B1 & .277 & 0.106 & 0.201 & 0.224 & $0.827 \%$ & 0.109 & 0.095 \\
\hline $\mathrm{B} 2$ & 180 & 0.053 & 0.244 & 0.195 & 0.699 & 0.134 & 0.071 \\
\hline E1 & 0.248 & 0.184 & 0.037 & 0.240 & 0.241 & 0.907 & 0.172 \\
\hline $\mathrm{E} 2$ & 0.032 & 0.190 & 0.305 & 0.141 & 0.187 & 0.301 & 0.173 \\
\hline $\mathrm{D} 4$ & 0.081 & 0.398 & 0.028 & 0.236 & 0.230 & 0.169 & 0.677 \\
\hline D5 & 0.161 & 0.076 & 0.133 & 0.132 & 0.008 & 0.048 & 0.225 \\
\hline Eigen value & 2.123 & 2.039 & 2.026 & 1.811 & 1.591 & 1.057 & 0.859 \\
\hline $\begin{array}{c}\text { Cumulative } \\
\text { contribution } \\
\text { rate }\end{array}$ & $11.8 \%$ & $23.1 \%$ & $34.4 \%$ & $44.4 \%$ & $53.3 \%$ & $59.1 \%$ & $63.9 \%$ \\
\hline $\begin{array}{c}\text { Definitions } \\
\text { of factors }\end{array}$ & $\begin{array}{l}\text { Conscious } \\
\text { ness of } \\
\text { greening }\end{array}$ & $\begin{array}{c}\text { Expectations } \\
\text { for } \\
\text { beautification }\end{array}$ & $\begin{array}{l}\text { Resistance } \\
\text { to activities }\end{array}$ & $\begin{array}{c}\text { Consciousnes } \\
\text { s of city } \\
\text { planning }\end{array}$ & $\begin{array}{l}\text { Secure } \\
\text { feeling }\end{array}$ & $\begin{array}{c}\text { Resistance } \\
\text { to other } \\
\text { people }\end{array}$ & $\begin{array}{l}\text { Expectations } \\
\text { for human } \\
\text { effects }\end{array}$ \\
\hline
\end{tabular}

Table 2 Evaluation items for assumed consideration

\begin{tabular}{|c|c|c|l|}
\hline No & Code & $\begin{array}{c}\text { Mean Value } \\
\text { in Evaluation }\end{array}$ & \multicolumn{1}{|c|}{ Evaluation items } \\
\hline \hline 1 & A1 & $1.55,1.32$ & I like glowing flowers. \\
\hline 2 & A2 & $1.45,1.43$ & I like have flowers and greens in my house. \\
\hline 3 & A3 & $1.34,1.28$ & I like seeing flowers and greens of others or other houses. \\
\hline 4 & B1 & $0.88,0.45$ & I have many acquaintances in the area where I live. \\
\hline 5 & B2 & $0.94,0.70$ & I am very familiar to the area where I live \\
\hline 6 & C1 & $0.30,0.06$ & I want to take up my opinion to the city planning. \\
\hline 7 & C2 & $0.28,-0.36$ & I want to attend a sym posium regarding the city plann ing. \\
\hline 8 & C3 & $0.38,-0.09$ & I want to participate in the festival or even ts in my com munity. \\
\hline 9 & D1 & $1.03,0.90$ & $\begin{array}{l}\text { The streets and the community will look better by maintaining } \\
\text { my garden. }\end{array}$ \\
\hline 10 & D2 & $0.78,0.72$ & $\begin{array}{l}\text { Maintenance of my garden helps greening and beautification of the } \\
\text { community. }\end{array}$ \\
\hline 11 & D3 & $1.17,1.30$ & Maintenance of my garden makes my neighborhood look beautiful. \\
\hline 12 & D4 & $0.67,0.27$ & Maintenance of my garden activates comm unity activities in the area. \\
\hline 13 & D5 & $-0.64,-0.44$ & I can expect some benefits through maintenance of my garden. \\
\hline 14 & E1 & $0.78,0.30$ & I like have chatting with people. \\
\hline 15 & E2 & $0.28,0.20$ & I am not concerned about other people's behaviors and what they say. \\
\hline 16 & F1 & $0.33,0.27$ & I do not mind if tasks to maintain my garden increase. \\
\hline 17 & F2 & $0.73,0.45$ & I do not mind spending time to main tain my garden. \\
\hline 18 & F3 & $-0.03,-0.05$ & I do not mind if I have to spend money more to maintain my garden. \\
\hline
\end{tabular}
*Mean Value in Evaluation (Open, Close)

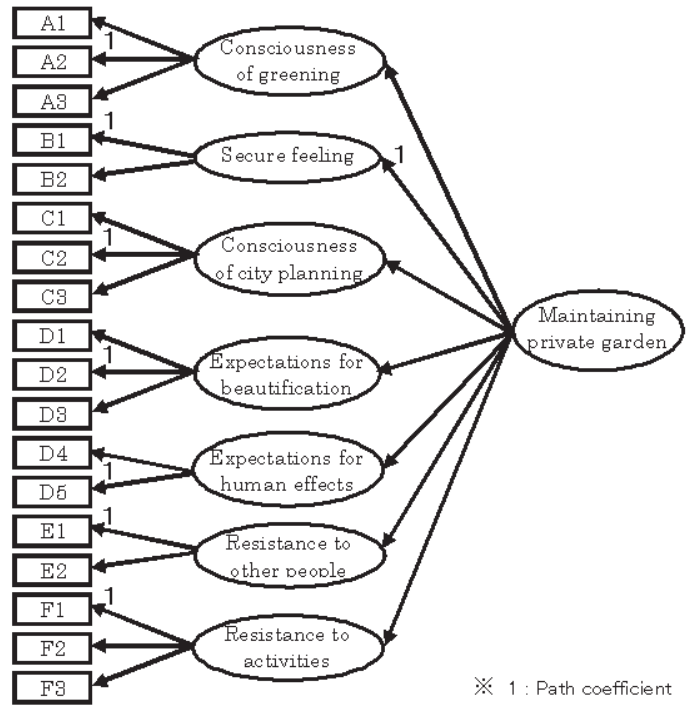

Fig. 4 Structural Model of Consciousness of Private garden (Path Chart)

15 in 2009). The authors selected the houses with a garden of which planting/green area was $10 \mathrm{~m}^{2}$ or greater, and the plants in the area looked growing or alive. The questionnaire included the questions on the consciousness hypothetically associated with the individual attributes and maintenance of their garden, and the OG evaluation (appeals, concerns and resistance to OG). The obtained individual attributes of the respondents are shown in Table 1 (what comes to the relation to personal attributes of the respondents, the older they are and/or the longer they live in the same place, their consciousness is relatively higher than the other group). The next section will elicit conclusions from total 150 collected response sheets excluding those from the sample residents who performed OG activities.

(1) lllustrating structure of consciousness associated with maintaining private garden

The consciousness associated with maintaining private garden appear to be associated with consciousness of greening, secure feeling in the social field, interests in city planning, effects of policies and consciousness of expectations, resistance to the other people and resistance to tasks according to the reference materials and the transforming process of consciousness (desires to appeal and pride, keep holding, expand the territory, promotion factors, etc.) (Fig.3). The authors set up questions related to the above (Table 2). The respondents were asked to answer the questions in 5-point scale: 1. No, I do not (not applicable), 2. Not so much, 3. Neutral, 4. Maybe, and 5. Yes, I do (applicable). For the information, the mean values of individual evaluations are calculated by 1) adding up the scores given by all respondents to the evaluation items, where the consciousness rated 5 in the five-point scale is +2 , and similarly 4 rated consciousness as $+1,3$ rated as 0,2 rated as -1 and 1 rated as -2 , and 2) dividing the grand total by the number of respondents. The positive values indicate that the respondents are highly conscious of the significance of and evaluate the OG activities, while the negative values indicate that the respondents are not. In the obtained responses, those to the questions highly correlated each other will be compiled, and be subjected to the factor analysis to highlight the residents' sub'consciousness and establish the latent variables in the covariance structural analysis. Table 3 shows the definitions of factor loading, eigenvalue, cumulative contribution rate and factors in the factor analysis (after the rotation 
Table 4 Results of Covariance Structural Analysis of Consciousnesses

\begin{tabular}{|c|c|c|c|c|c|}
\hline \multicolumn{3}{|c|}{ Relation of each variable } & \multirow{2}{*}{\begin{tabular}{|c|}
$\begin{array}{c}\text { Path } \\
\text { coefficient }\end{array}$ \\
0.499 \\
\end{tabular}} & \multirow{2}{*}{\begin{tabular}{|l}
$\mathrm{t}$-value \\
5.421 \\
\end{tabular}} & \multirow{2}{*}{\begin{tabular}{|l|} 
粎 \\
\end{tabular}} \\
\hline Consciousness of greening & $\mid<--$ & Maintenance of private garden & & & \\
\hline Secure feeling & $\mid<--$ & Maintenance of private garden & 1.000 & - & - \\
\hline Expectations for beautification & $\mid<---$ & Maintenance of private garden & 0.849 & 6.637 & 粎 \\
\hline Interests in city planning & $<---$ & Maintenance of private garden & 0.567 & 5.439 & 粎 \\
\hline Expectations for human effects & $<--$ & Maintenance of private garden & 0.793 & 6.808 & 米 \\
\hline Resistance to other people & $<---$ & Maintenance of private garden & 0.900 & 7.024 & 粎 \\
\hline Resistance to tasks & $<---$ & Maintenance of private garden & 0.571 & 4.165 & *米 \\
\hline A1 & $\mid<--$ & Consciousness of greening & 0.945 & 9.173 & *米 \\
\hline A2 & $\langle---$ & Consciousness of greening & 1.000 & - & - \\
\hline $\mathrm{A3}$ & $\langle--$ & Consciousness of greening & 0.987 & 8.428 & *** \\
\hline $\mathrm{B} 1$ & $\langle---$ & Secure feeling & 1.000 & - & - \\
\hline $\mathrm{B} 2$ & $\langle---$ & Secure feeling & 0.717 & 9.252 & *米 \\
\hline $\mathrm{C} 1$ & $\mid<---$ & Interests in city planning & 0.898 & 8.542 & 粎 \\
\hline $\mathrm{C} 2$ & $\langle--$ & Interests in city planning & 1.000 & - & - \\
\hline $\mathrm{C} 3$ & $<---$ & Interes ts in city planning & 0.981 & 8.579 & *米 \\
\hline D1 & $\mid<--$ & Expectations for beautification & 0.993 & 10.556 & 粎 \\
\hline D2 & $<---$ & Expectations for beautification & 1.000 & - & - \\
\hline D3 & $\langle--$ & Expectations for beautification & 0.528 & 6.265 & 粎 \\
\hline $\mathrm{D} 4$ & $\langle---$ & Expectations for human effects & 0.530 & 3.313 & 粎 \\
\hline D5 & $<---$ & Expectations for human effects & 1.000 & - & - \\
\hline E1 & $\mid<---$ & Resistance to other people & 1.000 & - & - \\
\hline E2 & $<---$ & Resistance to other people & 0.702 & 5.095 & 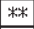 \\
\hline F1 & $\langle--$ & Resistance to tasks & 1.000 & - & - \\
\hline F2 & $\langle---$ & Resistance to tasks & 0.829 & 8.346 & 粎 \\
\hline F3 & $<---$ & Resistance to tasks & 0.609 & 6.681 & 粎 \\
\hline \multicolumn{3}{|c|}{ GF1 } & \multicolumn{3}{|c|}{0.865} \\
\hline \multicolumn{3}{|c|}{ AGF1 } & \multicolumn{3}{|c|}{0.820} \\
\hline
\end{tabular}

by the varimax method). Since Factor 1 is high in the factor loading with A1- "I like glowing flowers," A2 " I like have flowers and greens in my house," and A3- "I like seeing flowers and greens of others or other houses," it is defined as the conscious. ness of greening. Similarly, Factor 2 is defined as the conscious. ness of beautification, Factor 3 as resistance to tasks, Factor 4 as interests in city planning, Factor 5 as security feeling in the social field, Factor 6 as resistance to other people and Factor 7 as expectation for human effects (the number of factors is determined as seven according to the transforming process of con. sciousness and the factor loading values)
Table 5 Impotence of Observed Variables of Consciousness

\begin{tabular}{|c|c|c|c|c|}
\hline $\begin{array}{c}\text { Latent } \\
\text { variables } \\
\end{array}$ & $\begin{array}{c}\text { Path } \\
\text { coefficients } \\
\end{array}$ & Latent variables & $\begin{array}{c}\text { Path } \\
\text { coefficients } \\
\end{array}$ & $\begin{array}{l}\text { Observed } \\
\text { variables }\end{array}$ \\
\hline \multirow{18}{*}{$\begin{array}{c}\text { Maintenance } \\
\text { of private } \\
\text { garden }\end{array}$} & \multirow{3}{*}{0.499} & \multirow{3}{*}{ Consciousness of greening } & 0.945 & $\mathrm{~A} 1$ \\
\hline & & & 1.000 & A2 \\
\hline & & & 0.987 & A3 \\
\hline & \multirow{2}{*}{1.000} & \multirow{2}{*}{ Secure feeling } & 1.000 & B1 \\
\hline & & & 0.717 & B2 \\
\hline & \multirow{3}{*}{0.849} & \multirow{3}{*}{ Interests in city planning } & 0.898 & $\mathrm{C} 1$ \\
\hline & & & 1.000 & $\mathrm{C} 2$ \\
\hline & & & 0.981 & $\mathrm{C} 3$ \\
\hline & \multirow{3}{*}{0.567} & \multirow{3}{*}{ Expectations for beautification } & 0.993 & D1 \\
\hline & & & 1.000 & $\mathrm{D} 2$ \\
\hline & & & 0.528 & D3 \\
\hline & \multirow{2}{*}{0.793} & \multirow{2}{*}{ Expectations for human effects } & 0.530 & $\mathrm{D} 4$ \\
\hline & & & 1.000 & D5 \\
\hline & \multirow{2}{*}{0.9} & \multirow{2}{*}{ Resistance to other people } & 1.000 & $\mathrm{E} 1$ \\
\hline & & & 0.702 & E2 \\
\hline & \multirow{3}{*}{0.571} & \multirow{3}{*}{ Resistance to tasks } & 1.000 & F1 \\
\hline & & & 0.829 & F2 \\
\hline & & & 0.609 & F3 \\
\hline
\end{tabular}

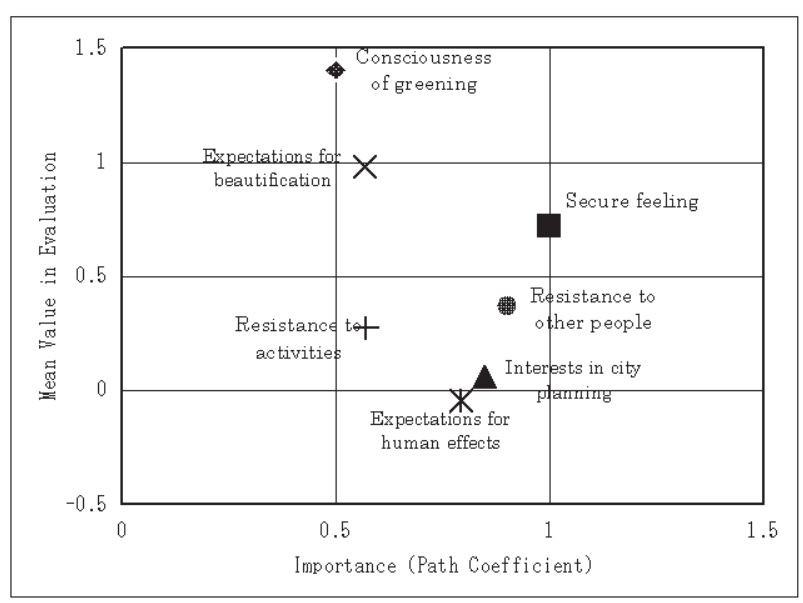

Fig.5 Importance of Consciousness (Path Coefficient) and Mean Values in Evaluation

The results of the factor analysis are defined as the latent consciousness of the residents, and they are used as the latent variables in the structural model of the resident consciousness for the purpose of this paper. The upper variables are given to (the consciousness associated with) maintaining private garden, and the latent variables obtained in the factor analysis between the observed variables and the upper variables to build the structural model of consciousness (path chart) by taking the preset consciousnesses into account (see Fig.4). Table 4 shows the results of the covariance structural analysis in the structural model of consciousness. For the information, Amos5.0 (SPSS) is used for the verification of the parameters. The covariance structural analysis resulted in that the parameters meet a significant level of $1 \%$. It demonstrates that all the preset consciousnesses exist (people have such consciousnesses) (AFGI 0.82000).According to the importance of the latent variables (path coefficients) in Table 5, the value of secure feeling is the highest at 1.000. It indicates that the secure feeling is most influential on the act to maintain their garden. According to the transforming process of consciousness, people have a strong consciousness associated with holding their space are those who strongly conscious of the act of maintaining their garden. The next highest is the resistance to other people at 0.900 followed by the interests in city planning at 0.849 , the expectations for human effects at 0.793 , the resistance to tasks at 0.571 , the expectations for beautification at 0.567 , and the consciousness of greening at 0.499 (the observed variables are in a similar order). Next, Fig 5 shows the relation between the importance of observed variables and the grade of each consciousness. Since the grade of consciousness shows a similar tendency to observed variables between the factors obtained by the factor analysis, it is compared by factor (for the mean values of the evaluation, see the above)。 The results will be discussed by adding the importance of the observed variables. It is expected that a desirable direction to maintaining private garden will be elicited by extracting and improving the highly important consciousnesses of lower mean values in Fig.5. From this perspective, it is desirable to improve the factors of secure feeling, resistance to other people, city planning, and expectations for human effects and resistance to tasks for such direction. In particular, taking the significance of the observed variables into account, if the relation with acquaintances deepens to increase the secure feeling which is a desire of stability, the consciousness associated with maintaining the garden will be improved further.

(2)Identifying disparities in structure of consciousness of people who open or close their garden to the public 
Table 6 Evaluation Items for Open Garden (Activities)

\begin{tabular}{|c|c|c|c|c|}
\hline & No. & Code & $\begin{array}{l}\text { mean value } \\
\text { in Evaluation }\end{array}$ & Evaluation Items \\
\hline \multirow{11}{*}{$\begin{array}{l}\text { Appeals of } \\
\text { Open } \\
\text { Garden }\end{array}$} & 1 & AA1 & $1.31,0.85$ & $\begin{array}{l}\text { What do you think about getting to know how to grow } \\
\text { flowers and greens, and deepening such knowledge? }\end{array}$ \\
\hline & 2 & AA2 & $1.22,0.68$ & $\begin{array}{l}\text { What do you think about getting know how to } \\
\text { designing the garden, and deepen such knowledge? }\end{array}$ \\
\hline & 3 & AA3 & $1.29,0.77$ & $\begin{array}{l}\text { What do you think about making your environments } \\
\text { beautiful? }\end{array}$ \\
\hline & 4 & $\mathrm{AA} 4$ & $1.30,0.74$ & $\begin{array}{l}\text { What do you think about contributing to improvement } \\
\text { of the view of your residential area? }\end{array}$ \\
\hline & 5 & AA5 & $1.07,0.29$ & What do you think about solving your stress? \\
\hline & 6 & AA6 & $1.02,0.20$ & $\begin{array}{l}\text { What do you think about having intercommunication } \\
\text { with neighbors? }\end{array}$ \\
\hline & 7 & AA7 & $0.95,0.26$ & What do you think about getting to know other people? \\
\hline & 8 & AA6 & $1.08,0.36$ & $\begin{array}{l}\text { What do you think about having connections with the } \\
\text { people in your residential area? }\end{array}$ \\
\hline & 9 & AA9 & $0.92,-0.09$ & $\begin{array}{l}\text { What do you think about showing your garden to } \\
\text { neighbors? }\end{array}$ \\
\hline & 10 & AA10 & $0.63,-0.23$ & $\begin{array}{l}\text { What do you think about earning good reputation } \\
\text { through your open garden? }\end{array}$ \\
\hline & 11 & AA11 & $-0.12,-0.29$ & $\begin{array}{l}\text { What do you think about, probably, you will obtain } \\
\text { some benefits from your open garden? }\end{array}$ \\
\hline \multirow{21}{*}{$\begin{array}{c}\text { Concerns } \\
\text { and } \\
\text { Resistance } \\
\text { to Open } \\
\text { Garden }\end{array}$} & 12 & $\mathrm{AB} 1$ & $-0.02,-0.91$ & $\begin{array}{l}\text { What do you think about tasks for maintaining your } \\
\text { garden will increase? }\end{array}$ \\
\hline & 13 & $\mathrm{AB} 2$ & $0.05,-0.91$ & $\begin{array}{l}\text { What do you think about tasks for taking care of plants } \\
\text { will increase? }\end{array}$ \\
\hline & 14 & AB3 & $-0.16,-1.26$ & $\begin{array}{l}\text { What do you think about clerical works such as binding } \\
\text { up guide maps? }\end{array}$ \\
\hline & 15 & $\mathrm{AB} 4$ & $-0.16,-1.29$ & $\begin{array}{l}\text { What do you think about clerical tasks for setting } \\
\text { guideboards, securing parking lots, etc.? }\end{array}$ \\
\hline & 16 & $\mathrm{AB5}$ & $-0.04,-1.03$ & $\begin{array}{l}\text { What do you think about increases in costs for plants, } \\
\text { flowers and your garden }\end{array}$ \\
\hline & 17 & $\mathrm{AB} 6$ & $-0.21,-1.18$ & $\begin{array}{l}\text { What do you think about disclosing the in formation of } \\
\text { your garden on the guide map? }\end{array}$ \\
\hline & 18 & AB7 & $0.14,-1.00$ & $\begin{array}{l}\text { What do you think about requests, expectations and } \\
\text { evaluation by the users of your open garden? }\end{array}$ \\
\hline & 19 & AB8 & $-0.11,-1.33$ & $\begin{array}{l}\text { What do you think about influences of the } O G \text { users' } \\
\text { eyes on your neighbors? }\end{array}$ \\
\hline & 20 & $\mathrm{AB} 9$ & $-0.76,-1.44$ & What do you think about your garden gets messy? \\
\hline & 21 & $\mathrm{AB} 10$ & $-0.97,-1.48$ & $\begin{array}{l}\text { What do you think about your properties are broken or } \\
\text { vandalized? }\end{array}$ \\
\hline & 22 & AB11 & $-0.72,-1.41$ & $\begin{array}{l}\text { What do you think about flowers are damaged or } \\
\text { picked up? }\end{array}$ \\
\hline & 23 & $\mathrm{AB} 12$ & $-0.93,-1.48$ & What do you think about your properties are stolen? \\
\hline & 24 & $\mathrm{AB} 13$ & $-0.35,-1.41$ & What do you think about noise made by the OG users? \\
\hline & 25 & AB14 & $-0.86,-1.54$ & $\begin{array}{l}\text { What do you think about someb ody enters your garden } \\
\text { other than the hours of opening? }\end{array}$ \\
\hline & 26 & $\mathrm{AB} 15$ & $-0.49,-1.41$ & $\begin{array}{l}\text { What do you think about somebody enters the place } \\
\text { closed to the public? }\end{array}$ \\
\hline & 27 & AB16 & $-0.57,-1.38$ & $\begin{array}{l}\text { What do you think about you are bound by the hours of } \\
\text { opening? }\end{array}$ \\
\hline & 28 & $\mathrm{AB} 17$ & $-0.35,-1.30$ & What do you think about the eyes of the OG users? \\
\hline & 29 & AB18 & $-0.56,-1.38$ & $\begin{array}{l}\text { What do you think about your activities are limited } \\
\text { during the hours of opening? }\end{array}$ \\
\hline & 30 & $\mathrm{AB} 19$ & $-0.68,-1.52$ & $\begin{array}{l}\text { What do you think about influences of parking bicycles } \\
\text { and cars on your neighbors? }\end{array}$ \\
\hline & 31 & AB20 & $-0.67,-1.53$ & $\begin{array}{l}\text { What do you think about influences of trash discarded } \\
\text { by the OG users on your neighbors? }\end{array}$ \\
\hline & 32 & AB21 & $-0.40,-1.43$ & $\begin{array}{l}\text { What do you think about influences of the noise by the } \\
\text { OG users on your neighbors? }\end{array}$ \\
\hline
\end{tabular}

Table 7 Results of Factor Analysis in Open Garden Evaluation (after Varimax Rotation)
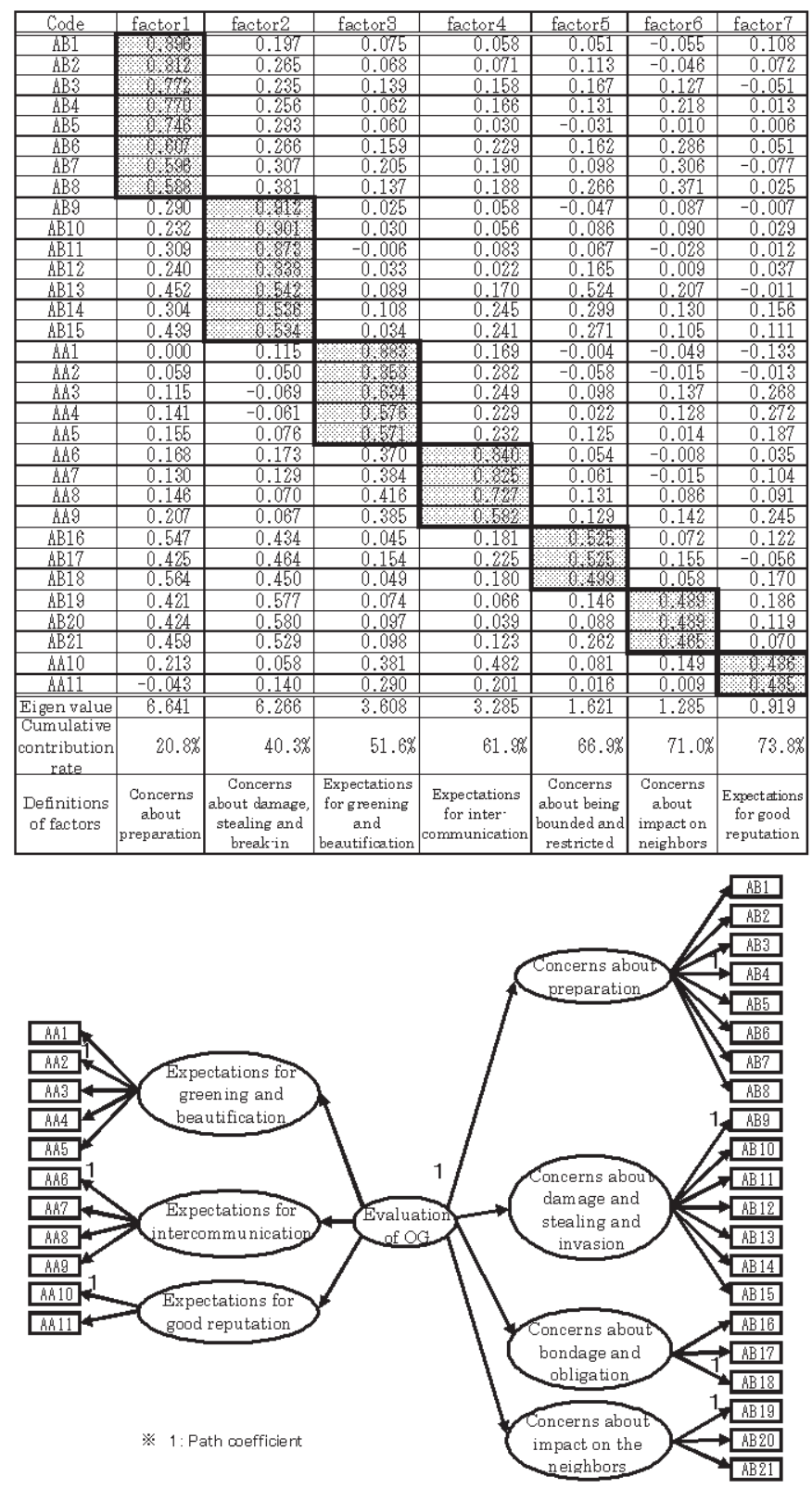

Fig.6 Structural Model of Open Garden Evaluation (Path Chart)

It is highly expected that, if people not only maintain their garden but also participate in the OG activities, their residential area and community will become sound and comfortable. To promote such city planning or orient it to such direction, this section will identify disparities in the structure of consciousness of between the people who open their garden to the public and those who do not, and isolate the issues lying there.

It is expected that to participate in OG activities heavily depends on the appeals (merits) of the OG and concerns and resistance associated with the activities (demerits). The OG evaluation, including the merits and demerits, will be conducted on the people who maintain their garden, while asking them if they participate in the OG activities. For the purpose of the evaluation, the appeals of the OG and concerns and resistance to the OG are listed in Table 6. The sample residents were asked to complete the questioner for the prescribed evaluation items in the 5-point scale. For the aspects of the appeals of the OG are rated as follow: 1. Not appealing, 2. Not so much appealing, 3 . Neutral, 4. Somewhat appealing, and 5. Very appealing. On the other hand, the concerns and resistance to the OG are rated as follow: 1 . Very concerned(anxious), 2. Somewhat concerned, 3. I do not know, 4. Not so much concerned, and 5. Not concerned(not anxious). Incidentally, the survey asked the sample residents whether or not they want to participate in the OG activities on the 4-point scale as follow: Very much, Maybe, Not so much and Not at all.

Therefore, firstly, the relevancy between the level of consciousness about maintenance management and the cases with or without participation in the OG activities will be analyzed. Some sort of relationship (The ratio of the people who open their gardens to the public: Highly conscious people of $68.3 \%$, Less conscious people of $31.7 \%$; The ratio of the people who do not open them: Highly conscious people of $43.1 \%$, Less conscious people 
Table 8 Importance of Observed Variables in Open Garden Evaluation

of $56.9 \%$ ) was indicated also by the level of consciousness (Highly conscious persons: Average of 44.4, Standard Deviation of 3.52, Highly conscious persons: Average value of 33.7, Standard deviation of 5.55 *Maximum value of 56, Minimum value of 11.2) and the cases with or without participation in the $O G$ activities in terms of the examination of independency ( $x 2=7.55$, p value $=0.006,1 \%$ Significant lebel $)$, both of which are derived by dividing the total score of consciousness about maintenance management calculated according to List 5 (Each an· swer of the 5-point scale evaluation multiplied by the bus coefficient) by a half of the total answers. The factors for it, however, are not definite. So, the following analysis will be made to clarify them.

First, all the obtained responses (regardless of participation or not in the OG activities) were subjected to the factor analysis similarly to the consciousness associated with maintaining the respondents' garden (Table 7). As the result, Factor 1 is defined as Concerns about preparation, Factor 2 as Concerns about dam. age, stealing and break-in, Factor 3 as Expectations for greening and beautification, Factor 4 as Expectations for intercommunication, Factor 5 as Concerns about being bound and restricted, Factor 6 as Concerns about impact on the neighbors and Factor 7 as Expectations for good reputation.

Next, the path chart was plotted using the results of the factor analysis (Fig.6), and the covariance structural analysis was performed (Table 8). According to the results of the covariance struc-

\begin{tabular}{|c|c|c|c|c|c|c|c|c|}
\hline \multirow{2}{*}{$\begin{array}{c}\begin{array}{c}\text { Latent } \\
\text { variables }\end{array} \\
\end{array}$} & \multicolumn{3}{|c|}{ Path Coefficients } & \multirow{2}{*}{ Latent Variables } & \multicolumn{3}{|c|}{$\begin{array}{l}\text { Path Coefficients } \\
\end{array}$} & \multirow{2}{*}{$\begin{array}{l}\text { Observed } \\
\text { Variables }\end{array}$} \\
\hline & Overall & Open & Close & & \begin{tabular}{|l|} 
Overall \\
\end{tabular} & Open & Close & \\
\hline \multirow{32}{*}{$\begin{array}{l}\text { Open Garden } \\
\text { Evaluation }\end{array}$} & \multirow{5}{*}{$0.281^{*}$} & \multirow{5}{*}{0.158} & \multirow{5}{*}{0.408} & \multirow{5}{*}{$\begin{array}{l}\text { Expectations for } \\
\text { greening and } \\
\text { beautification }\end{array}$} & $0.899^{* *}$ & 0.991 & $0.882^{* *}$ & Ah1 \\
\hline & & & & & 1.000 & 1.000 & 1.000 & $\mathrm{~m} 2$ \\
\hline & & & & & $0.640^{* * 4}$ & $0.422^{*}$ & $0.662^{* *}$ & this \\
\hline & & & & & $0.611^{* *}$ & 0.331 & $0.663^{* *+}$ & An 4 \\
\hline & & & & & $0.773^{\mathrm{kx}}$ & $0.436^{*}$ & $0.803^{\text {** }}$ & AM5 \\
\hline & \multirow{4}{*}{$0.541^{* *}$} & \multirow{4}{*}{0.140} & \multirow{4}{*}{$0.6911^{* *}$} & \multirow{4}{*}{$\begin{array}{l}\text { Expectations for } \\
\text { intercommunicat } \\
\text { ion }\end{array}$} & 1.000 & 1.000 & 1.000 & $m 6$ \\
\hline & & & & & $0.975^{\text {** }}$ & $1.071^{*}$ & $0.984^{* *}$ & Ain 7 \\
\hline & & & & & $0.859^{* *}$ & $0.920^{*}$ & $0.842^{* * *}$ & $\sin 8$ \\
\hline & & & & & $0.752^{* *}$ & $0.463^{*}$ & $0.786^{* *}$ & $\sin 9$ \\
\hline & \multirow{2}{*}{$0.542^{* *}$} & \multirow{2}{*}{0.290} & \multirow{2}{*}{$0.627^{* *}$} & \multirow{2}{*}{$\begin{array}{l}\text { Expectations } \\
\text { for good } \\
\text { reputation } \\
\end{array}$} & 1.000 & 1.000 & 1.000 & $\$ 410$ \\
\hline & & & & & 0.442 & 1.469 & 0.396 & An11 \\
\hline & \multirow{7}{*}{1.000} & \multirow{8}{*}{1.000} & \multirow{7}{*}{1.000} & \multirow{7}{*}{$\begin{array}{c}\text { Concerns } \\
\text { about } \\
\text { preparation }\end{array}$} & $0.939^{* *+}$ & $0.955^{* *}$ & $1.063^{* *}$ & $\mathrm{AB1}$ \\
\hline & & & & & $0.883^{* *}$ & $0.821^{* *}$ & $0.972^{* *}$ & $\mathrm{AB} 2$ \\
\hline & & & & & $0.936^{* *}$ & $0.819^{\text {** }}$ & $.012^{* *}$ & $\mathrm{AB} 3$ \\
\hline & & & & & 1.000 & 1.000 & 1.000 & $\mathrm{AB4}$ \\
\hline & & & & & $0.842^{* *}$ & $0.648^{* * *}$ & $0.995^{* *}$ & $\mathrm{AB} 5$ \\
\hline & & & & & $0.866^{* \prime}$ & $0.834^{* *}$ & $0.878^{* *}$ & $A B 6$ \\
\hline & & & & & $\left.0.850^{* *}\right]$ & $0.807^{* *}$ & $0.767^{* *}$ & $\mathrm{AB} 7$ \\
\hline & \multirow{8}{*}{$0.817^{* *}$} & & \multirow{8}{*}{$0.757^{*}$} & \multirow{8}{*}{$\begin{array}{l}\text { Concerns about } \\
\text { damage, stealing } \\
\text { and invasion }\end{array}$} & {$\left[0.861^{\prime \prime}\right]$} & $0.830^{\circ \prime \prime}$ & 0.728 & $A B 8$ \\
\hline & & \multirow{7}{*}{$1.378^{* *}$} & & & & 1.000 & 1.000 & AB9 \\
\hline & & & & & 0.91 & 0.978 & .982 & AB10 \\
\hline & & & & & $0.978^{* *}$ & $0.955^{* *}$ & $.996^{* *}$ & $\mathrm{AB11}$ \\
\hline & & & & & $0.982^{* *}$ & $0.967^{* *}$ & $1.052^{* *}$ & $\mathrm{AB} 12$ \\
\hline & & & & & $0.869^{* *}$ & $0.728^{* *}$ & $.861^{* *}$ & $\mathrm{AB} 13$ \\
\hline & & & & & $0.643^{* *}$ & $0.638^{8 * *}$ & $.550^{* *}$ & $\mathrm{AB14}$ \\
\hline & & & & & $0.828^{* * 4}$ & $0.788^{* *}$ & $0.731^{*+}$ & $\mathrm{AB15}$ \\
\hline & & & & Concerns about & $0.971^{* * 4}$ & $0.992^{* *}$ & $0.951^{* *}$ & AB16 \\
\hline & $0.966^{* *}$ & $1.127^{* 4}$ & $1.040^{* *}$ & being bounded & $0.841^{* *}$ & $0.774^{* *}$ & $0.776^{* *}$ & AB17 \\
\hline & & & & or restricted & 1.000 & 1.000 & 1.000 & $\mathrm{AB} 18$ \\
\hline & & & & Concerns about & 1.000 & 1.000 & 1.000 & $\mathrm{BB} 19$ \\
\hline & $0.918^{* *}$ & $1.402^{*+}$ & $0.808^{* *}$ & influences on & $0.944^{* *}$ & $0.937^{* *}$ & $0.886^{* *}$ & $\mathrm{AB} 20$ \\
\hline & & & & the neighbors & $0.968^{* *}$ & $0.872^{* *}$ & $0.927^{* *}$ & AB21 \\
\hline Num of & 150 & 41 & 109 & & & & & \\
\hline GFI & 0.729 & 0.609 & 0.679 & & & & $5 \% \mathrm{si}$ & ificant level \\
\hline AGFI & 0.671 & 0.533 & 0.614 & & & & & \\
\hline
\end{tabular}
tural analysis on all data, the individual latent and observed variables satisfy the level of significance (AGF1: 0.671). Based on the fact, the postulated structural model of consciousness was used for the structural model of consciousness for the OG evaluation.

\section{(2.1)Disparities in importance of latent and observed variables in $O G$ evaluation}

In the defined structural model, the covariance structural analysis was done on the attributes, i.e., the people who wanted to open their garden to the public (respondents who chose Very much and Maybe to the question if they want to participate in the OG activities or not) and those who did not (respondents who chose Not so much and Not at all) by case. As the result, the disparities were found between the importance and the significance level in the latent and observed variables (path coefficients).

First, in the appeals of the OG, each importance for the people who want to open their garden to the public is as follow: 0.158 for the expectations for greening, 0.140 for the expectations for intercommunication and 0.290 for the expectations for good reputation. In comparison, for the people who do not, the importance is as follow 0.408 for the expectations for greening and beautification, 0.691 for the expectations for intercommunication, and 0.627 for the expectations for good reputation. The importance of each latent variable for the people who do not open their garden to the public is higher than those who do. It indicates that people who do not open their garden to the public is more influenced by the merits (appeals) of the OG than those who do. Since these results are related to the evaluation mean values, they will be discussed collectively in the next section (2.2).

Next, in the concerns and resistance to the OG, each importance for the people who open their garden to the public is as follow: 1.000 for the concerns about preparation (path coefficient), 1.378 for the concerns of damage, stealing, and break $\cdot$ in, 1.127 for the concerns about being bounded and restricted and 1.402 for the concerns about impact on the neighbors. Each latent variable and the importance of the latent variable are relatively high and significant. Each importance for the people who close their garden to the public is also significant as follow: 1.000 for the concerns about preparation, 0.757 for the concerns of damage, stealing, and break ·in, 1.040 for the concerns about being bounded and restricted and 0.808 for the concerns about impact on the neighbors. With either of the attributes, it is not indicated that the importance of latent and observed variables of the concerns and resistance is high but that the low importance of the concerns and resistance is more influential. The disparity in the importance of individual latent and observed variables of the concerns and resistance implies that there is small disparity between the people who open their garden to the public and those who do not. As discussed in the appeals of the OG, since the results are also related to the evaluation mean values, they will be discussed collectively in the next section (2.2).

\section{(2.2)Disparities in mean values of $O G$ evaluation}

To identify the above disparities and study the direction toward the OG, the relation between the importance of observed variables and 


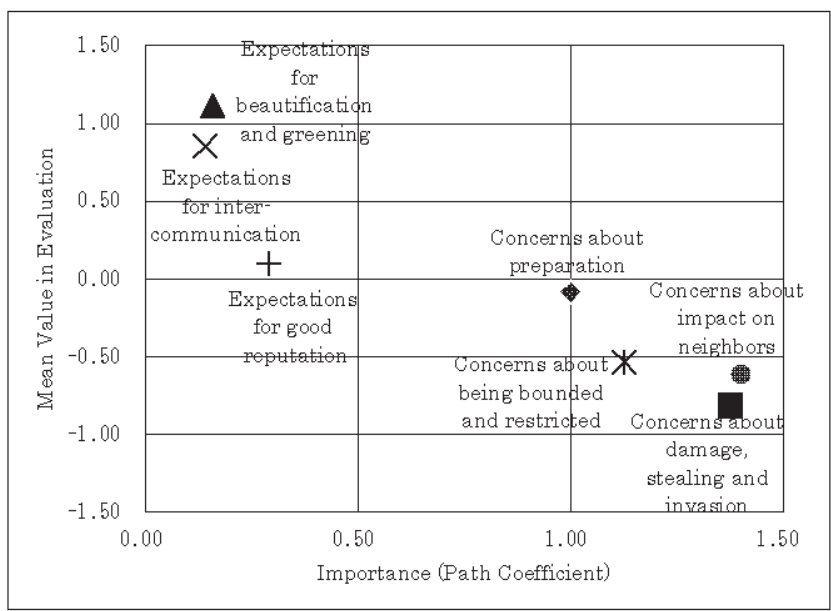

Fig. 7 Mean Value of Importance of OG Evaluation of People who open their garden

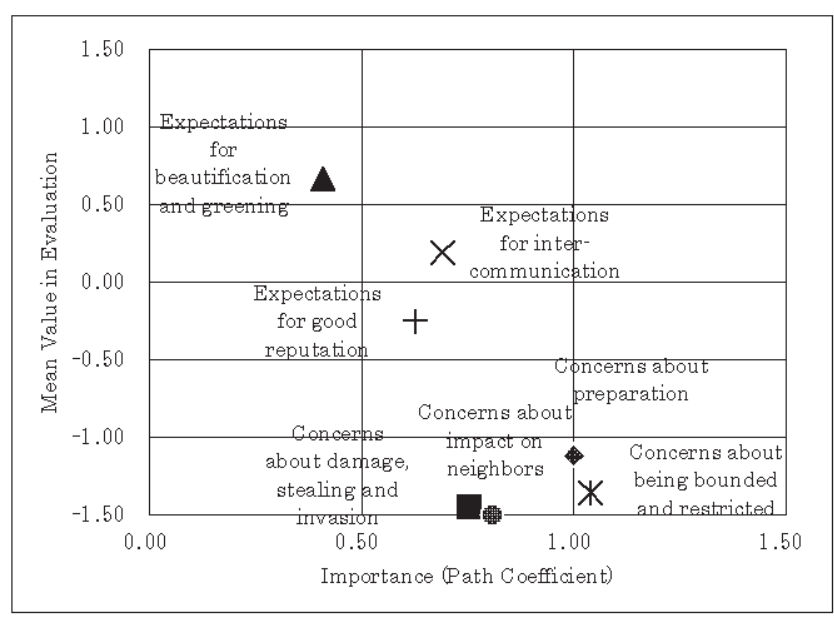

Fig. 8 Mean Value of Importance of OG Evaluation of People who close their garden

each rated consciousness (evaluation mean values) is plotted for the people who open the garden to the public and those who do not as shown in Fig. 7 and Fig. 8. For the information, they are compared by factor as done for the consciousness associated with maintaining their garden, and the evaluation mean values are calculated by the same method as for the said consciousness.

As the result, it is found that, first from comprehensive standpoint, the people who open their garden to the public highly evaluate (are conscious of) all the appeals and concerns and resistance to the OG in comparison with the people who do not. In other words, the OG evaluation results are higher among the people who open their garden to the public than those among the people who do not. Among both people who open their garden to the public and those who do not, the merit aspects of the appeals of the OG mark higher (preferable) mean values than the demerit aspects of the concerns and resistance to the OG.

Next, the aspects of appeals (merits) in the OG evaluation will be discussed. The evaluation mean values are high and come in the descendant order from expectations for greening and beautification, expectations for intercommunication to expectations for good reputation. Of them, the evaluation mean values of expectations for greening and beautification, expectations for intercommunication are high among the people who open their garden to the public, while those of expectations for greening and beautification are high among the people who do not. As to the relation between the mean values and the importance of the evaluation, these factors already earn high evaluation (consciousness), whereby the options to develop merits are limited to some extent or people are not so much conscious of the aspects of appeals, the importance might lower. For the process that the people who close their garden to the public change their mind to open their garden to the public, as the process proceeds, the evaluation mean values of the appeals are up, whereas the importance lowers. Although the mean value of the expectations for good reputation is rather low among the people who open the garden to the public (almost equivalent to that of the people who do not), the importance is low and not significant. It implicates that the people do not seek benefits from the OG activities.

First, in the aspects of concerns and resistance (demerits), the evaluation mean values of all aspects of the concerns and resistance are zero (0) or lower for the people who open their garden to the public and those who do not. It shows that the people are concerned and resistant to the $O G$, and these concerns and resistance lead the poor evaluation. There is a disparity that the people who close the garden to the public show lower evaluation mean values than those who open (i.e. lower consciousness of the concerns and resistance to the OG). To close the disparity, the concerns and resistance should be improved (mitigated), or orient them closer to those of the people who open the garden to the public. For the process that the people who close their garden to the public are closing to those who open their garden to the public, the mean values simply increase in the OG evaluation of the self factors, namely, concerns about preparation and concerns about being bound and restricted (the importance shows a similar trend). In contrast, as the external factors (moral factors of the OG users) are rated high, the importance increases proportionally. Therefore, as the consciousness of the people who close the garden to the public closes to that of the people who open the garden to the public, people become more attentive or have stronger attention to other people than themselves. This fact appears to be responsible for the expectation that it will contribute to town or city planning.

As to the directions to increase the consciousness associated with opening the garden to the public, it is considered as appropriate for the people who open their garden to the public to implement the policies to remove or mitigate the external factors of concerns about the impact on the neighbors and the concerns about damage, stealing and break -in, of which mean values are low; and appropriate for the people who do not to implement the policies to remover or mitigate the self factors of concerns about preparation and concerns about being bound and restricted. These will move the consciousness associated with closing the garden to the public close to the conscious ${ }^{*}$ ness associated with opening their garden, and make it possible to build healthier town. 


\section{Conclusion}

This study is intended to draw indexes of the consciousnesses in the process to maintaining private garden, i.e., the process to create a social field, identify the disparities between the consciousnesses of opening and closing private garden and isolate issues in the process through the survey of consciousness of the residents. The findings are as follow:

(1)Through developing a hypothetical transforming process of consciousness, conducting the questionnaire survey, factor and covariance structural analyses, the transforming process of consciousness was demonstrated, while it was found that the consciousness associated with maintaining private garden was most influenced from the secure feeling in the social field which is a desire to keep holding the territory. It is expected that improving the consciousness of secure feeling will increase the consciousness associated with maintaining private garden. Next, it is found that the consciousness of the open garden is influenced by the resistance to other people, interests in city planning, expectations for human effects, resistance to tasks, and expectations for beautification and consciousness of greening in descending order.

(2)through factor and covariance structural analyses on the similarly obtained data to the above, the structural model of the OG evaluation was defined, and thereby, the authors identify the importance (path coefficient) of the evaluation of the people who open or close their garden to the public, and the disparities between them from the high marks in the evaluation. As the result, the importance of the concerns and resistance to the OG was higher than the appeals of OG, and the evaluation mean values were low (the mean values of concerns and resistance to the OG were high). Including the above, as the direction to improving the conscious. ness associated with opening the garden to the public, it is considered appropriate for the both groups to implement the policies to remove or mitigate the concerns of the external factors such as concerns about the impact on the neighbors and concerns about damage, stealing and break-in, and for the people who close their garden to the public to promote the policies to remove or mitigate the selfffactors of concerns about preparation and concerns about being bound or restricted. These are considered as a proper direction to orient the residents to the consciousness associated with opening their garden to the public.

The survey of residents' consciousness identified part of the process of creating a social field. Based on the existing research results regarding $O G$, gardening, etc., it is demonstrated that each consciousness considered as a factor of constancy and continuity for these activities also has influence on people's creating social field. Many enigmas, however, remain unsolved by merely shedding light on part of the process of making a decision to start and/or continue the OG activities. It is important to continue to comprehensively study and discuss the consciousness by every phase until people open their garden to public; they decide to continue the activity, etc. This paper quantitatively explain the disparities in the feeling of resistance to the OG project among people who do not participate in the project, and such disparities significantly influence on the decision making process to open the garden. Since effects of the specific measures to increase the residents' consciousness and evaluation mean values are not yet to be quantified, the authors rather hesitate to mention but consider it desirable for the development of OG activities and the future town or city planning to focus on and promote mitigating the concerns and resistance to the $O G$ of the people who are not yet to open the garden.

\section{Reference}

1)Kobayashi, H: TERRITORYSTUDY OF COLLECTIVE HOUSING,Syukokusya, 1992

2)Kobayashi, H: STUDY ON "TERRITORY OF GROUPED INHABITANTS" IN SMALL HOUSING GROUPS,The University of Tokyo degree thesis 3)Newman, O:DEFENSIBLE SPACE, New York:Macmillan, 1972

4)Suzuki, N:"HOUSE" AND “TOWN",Kashimasyuppansya, 1984

5)Saito, H:THE RESIDENTS' EVALUATION OF DISTRICT PLANNING SYSTEM AND BUILDING AGREEMENT AS MANAGEMENT RULES OF LIVING ENVIRONMENT AT PLANNED DETACHED HOUSES AREAS, Journal of architecture planning513,pp205·212,1998.11

6)Tsukahara, $\mathrm{M}$ et al:Research on resident evaluation at use stage in community zone, Journal of the City Planning Institute of Japan, No.42 3 ,pp679 $684,2007.10$ 7)Kamata, M. et al:STUDY ON THE COMMUNITY OF NEW RESIDENTS' ASSOCIATION IN RURAL·URBAN FRINGE ·Case study of the reorganized residents' association by coexisting phenomena',Journal of architecture planning555,pp2 15·222,2002.5

8)Saitou, H:The Study on Impact of Street Layout Affecting Community Development in the Planned Detached houses Area,Papers on city planning36,pp475·480,2001.10 9)Saitou, H:A STUDY ON RESIDENTS' ATTITUDE AND ITS FACTORS ON FORMULATING URBAN LANDSCAPE FROMTHE LIVING ENVIRONMENT MANAGEMENT POINT OF VIEW AT DETACHED HOUSES AREAS,Journal of architecture,planning505,pp 143 $149,1998.3$

10)Inoue, Y. et al:A STUDY ON THE PERSONALIZATION OF RESIDENTS IN NURSING HOME Studies on social welfare institution for the elderly from the aspect of dwelling $1 \cdot$,Journal of architecture planning501,pp 109·115,1997.11

11)Hino, K. et al:FRESIDENTS' ATTITUDE TOWARD MEASURES TO PREVENT CRIME IN CONDOMINIUMS ·Concerning newly published standard to certify secured condominiums', Journal of architecture plannin611,pp53·58,2007.1

12)Saito, H:Study of Influence Factor on Crime Prevention at Housing, Journal of the City Planning Institute of Japan38,pp223·228,1991

13)Nakanishi, Y.Discriminant analysis of point that causes anxiety in public parks in urban area, Journal of the City Planning Institute of Japan40,PP619.624,2005 14)Hashimoto, $\mathrm{K}$ et al:A STUDY ON THE PSYCHOLOGICAL TERRITORY BASED ONEXPERIMENTS OF INTERPERSONAL HORIZONTAL DISTANCE, Journal of architecture,planning485,pp 135·142,1996.7

15)Ikkai, YTHE PSYCHOLOGICAL EFFECT OF PUBLIC·PRIVATE PARTITIONING OF SPACE INTHE STREETS OF RESIDENTIALAREA,Journal of architecture planning526,pp2 15·222,1999.12 
16)Aida, A et al:The Origin and Development of Open Gardens Under the National Gardens Scheme in England and Wales,journal of the Japanese Institute of Landscape Architecture Vol65(5),pp393·396,2002

17)Nonaka, S:A Study on the Behavioral Characteristic of Appreciator of the Private Gardens Open to the Public Usually ·A case study of "Open Gardens" in Obuse Town ', Journal of the City Planning Institute of Japan40·3,pp847 852,2005

18)Nonaka, S:The Characteristics and Problem of"Open Gardens" in Obuse Town,journal of the Japanese Institute ofLandscape Architecturel65(5),pp805.810,2002 19)Altman. I.,The environment and social be0havior, Monterey,Brooks/cole, 1975

20)El·Sharkawy :Territoriality 'a model for architectural design' ,Dissertation for the degree of Ph.D., University of Pennsylvania, 1979

21)Saitou, H:A STUDY ON LANDSCAPE AND COMMUNTTY DEVELOPMENT THROUGH GREEN MANAGEMENT OF COMMON SPACES IN DETACHED HOUSING AREAS, Journal of architecture planning528,pp $163 \cdot 169,2000.2$

22)Narukawa, K. et al:THE EFFECT OF CHANGE IN SPATIAL CHARACTERISTICS ON VOLUNTARY GREENING BY REBUILDING OF MULTIPLE DWELLING HOUSES ·A study on design method for inducing voluntary greening in multiple dwelling houses', Journal of architecture,planning552,pp 161·168,2002.2

23)Kawane, A. et al:Attitude of the Residents toward Private Gardening in Megumino, Hokkaido,journal of the Japanese Institute of Landscape Architecture63(5), pp695·700,2000.3

24)Fujisaki, K etal:The Study on Communications among Inhabitants through Landscape Plants of Detached Housing Areas in New Housing Developments, Papers on environmental information science14,pp97 $102,2000.11$

25)Kamei, Y. et al:A STUDY ON FRONT YARDS AND STREET'SCAPES IN SUBURBAN HOUSING DEVELOPMENT PRACTICES 'The changing process of ready-build houses for sale in Japan Part 2', Journal of architecture and planning590,pp9·15,2005.4

26)Urayama, M et al:A Study on the Cooperative River Management of NPO, River Authority and Local Citizens 'A Case of "Asakura·Gawa Ikusui Forum" as a NPO in Toyohasi City, Aichi Prefecture, Journal of the City Planning Institute of Japan42 3,pp829 834,2007.10

27)Hayashi, M. et al:The Activities for Community Design covered with Green and the Factors for Promoting those,Papers on environmental information science $14, \mathrm{pp} 85 \cdot 90,2000.11$

28)Sanbuichi, J etal:An Examination about Structure of Consciousness of Open Gardenerjournal of the Japanese Institute of Landscape Architecturel70(5),pp391·396,2007 29)Demographic book in Mebashi

30)Toyoda, H:Covariance analysis,Asakurasyoten, 1998

\section{和文要約}

1・はじめに

我が国は、多くのハード・ソフト面が整備された。その結果、 各々の利便性は向上され、地域の人・場所から離れた生活を送る ことが可能となったが、人との接触回数が減ると共に地縁関係は 低下し、生活領域の管理する意識も低下した。このことから、整 備が生活環境の全ての面を良好にしたとはいいがたい。これまで の経緯から外面だけでなく、人々の内面的なことも考慮した計画 が必要であったことが伺え、今後の都市計画においてもそのよう な計画が重要になってくると考えられる。

\section{2. 研究目的}

本研究は人々の意識に着目し、「なわばり学(領域学)」を基に 領域化していく意識の変遷を明らかにし、内面的な計画の一助と していく。なお本論は、空間を領域化していく過程の中の（1） $「$ 自宅の庭 (一次領域・中心領域) の維持管理」での意識構造の 把握と、「閉鎖する人」との違いを通しての(2)「開放する意識」 の意識を把握することを目的としたものである。

\section{3. 研究方法}

目的 (1)「自宅の庭の維持管理をする意識構造」の把握では、 まず関連する意識を仮定し、それに伴う質問項目を設定する。そ れを含んだアンケート調査を自宅の庭を維持管理している人に実 施する。得られた全ぎー夕から因子分析、共分散構造分析を行 い、意識の有無上観測変数の重要度 (パス係数) を定量的に明ら かにすると共に、意識の高さとの関連加ら考察を行う。

目的（2）「開放する意識の意識構造を把握するこん」において は、(開放する) 行為をする際に「行為への魅力」と「行為への
不安・抵抗」が大きく影響すると考えられることから、それらの 各評価項目と開放する行為の参加の有無を尋ねた。得られた全回 答から因子分析、共分散構造分析を通して開放する人、閉鎖する 人の潜在、観測変数の重要度と評価の高さの違いから、それらの 差異や問題点、またその行為へ向かわせるための方向性を明らか にする。

\section{4. 研究結果}

住民の意識調査を通じて、本論で得られた知見は、以下のとお りである。

（1）「自宅の庭を維持管理する」という意識は、「領域を持続する」 という欲求の「(領域の) 安心感」が最も影響を与えていること が分かり、意識の高さ（評価平均值）を考慮すると、その意識を より高めることが空間を維持管理する意識を高めることに繋がる 上予測される。また、その次に「人への抵抗感」、「まちづくりの 意識」、「人的効果への期待」、「作業への抵抗感」、「美化効果への 期待」、「緑への意識」と順に影響を与えていることも明らかと なった。

(2) 開放する人は閉鎖する人の両者己も、「(開放する) 行為への 魅力」よりも「行為へ不安・抵抗」の重要度は高く、またその（評 価の) 高さも低い( $0 \mathrm{G}$ の不安・抵抗は高い)。これらを含め開放 する意識を高めるための方向性しして、両者によって評価平均值 が低かった「周辺影響への不安」や「破損・盗難・侵入への不安」 である外的要因の不安を取り除く・低減させる政策を徹底させ、 また閉鎖的な人にはさらに「準備への不安」や「拘束・束縛への 不安」である自己的要因を解消・低減させる政策を促していくこ とが開放する意識に近づけるための良い方向性だと思われる。 